\title{
Comparative Study on Flexural Performance of Foamed Concrete Beam Containing Plastic Fibers
}

\author{
Manthar Ali Keerio ${ }^{1 *}$, Muhammad Tahir Lakhiar ${ }^{2}$, Samiullah Sohu ${ }^{3}$ \\ ${ }^{1}$ Department of Civil Engineering, \\ Quaid-e-Awam University College of Engineering Science \& Technology (QUCEST), Larkano, PAKISTAN \\ ${ }^{2}$ Department of Civil Engineering, \\ Mehran University of Engineering \& Technology (MUET), Jamshoro, PAKISTAN \\ ${ }^{3}$ Department of Civil Engineering, \\ Quaid-e-Awam University College of Engineering Science \& Technology (QUCEST), Larkano, PAKISTAN
}

\section{*Corresponding Author}

DOI: https://doi.org/10.30880/ijscet.2019.10.01.001

Received 01 December 2018; Accepted 18 May 2019; Available online 01 June 2019

\begin{abstract}
Foamed concrete is considered as light weight concrete which possesses lot of benefits in context of speedy construction, light weight and durability. In this study, foamed concrete beam, containing the plastic fibers were analyzed under flexural load by experimentally and also by finite element analysis in terms of load bearing capacity, load deflection profile and cracking pattern. The Finite element analysis (FEA) was conducted by utilizing ABAQUS software to simulate the foamed concrete beam under flexure load. The beam consist the dimension was $100 \mathrm{~mm}$ thickness, 200mm breadth, $1000 \mathrm{~mm}$ length. The experimental and FEA outcomes were compared in context of the beam's ultimate load, load deflection and cracking pattern. The outcomes demonstrate that the difference between ultimate load was 5 to $8 \%$ between FEA and experimental results whereas the maximum deflection was 3 to 7 \% decreased in FEA compare to the experimental analysis. The parametric was conducted by changing the reinforcement area the results demonstrates that by increasing the main reinforcement area the ultimate load was rises and deflection was decreases compare to the control sample.
\end{abstract}

Keywords: foamed concrete beam, flexural load, FEA, plastic fibers

\section{Introduction}

Foamed concrete is known as light weight foamed concrete where the air bubbles are generated by incorporating the foaming agent which decreases the density of concrete comparative to normal or conventional concrete (Mohamad et al., 2017 and Goh et al., 2015). It is almost 87\% lighter by weight than the conventional concrete (Tharkele et al., 2014), where its density is directly influence by the incorporation of foamed (Chen et al., 2014 and Tang et al., 2018). The low density foamed concrete endorses little stress on the infrastructures. In the foamed concrete the coarse aggregate is not present (Ramamurthy et al., 2006 and Narayanan et al., 2000). Foamed concrete comprises of binder, sand, water and foaming agent. The $75 \%$ volume cover by the binder, sand, water and foaming agent the remaining 25\% volume cover by air (Aldrigde 2005). The foamed accomplishes to enlarge the concrete, increase the volume of 
blend, self-compaction and lighter in weight (Lakhiar et al., 2018a and Aghaee et al., 2014). In general words, foamed concrete is preferred as innovative and sustainable construction product for its benefits mentioned above. Moreover, the nonappearance of coarse aggregate in foamed concrete is responsible to shrinkage cracks. Cracks has plays vital in concrete which creates the high permeability in concrete, strength will be low and effect the durability of concrete (Ahmad 2015 and Neville 2001). Therefore, this research examined the behavior of foamed concrete beam consisting plastic fibers (PF). PF is a waste which is obtained from the old plastic bags as shown in Figure 1. Great number of scholars have conducted their research to investigate the structural behavior of foamed concrete beam. The conclusion was, $0.6 \%$ of $\mathrm{PF}$ are optimum containing percentage to enhance mechanical properties and also behavior of foamed concrete in terms of ultimate load and cracking pattern (Lakhiar et al., 2018b) Although foamed concrete has been greatly utilized in construction industry for ages, still lot of research is requiring to fill the gap in context of structural performance of foamed concrete beam under flexural load. Plastic Fibrous lightweight foamed concrete has high potential capability to be established further as construction material. It could be operated in the small and high-rise construction projects due to its high durability, flexibility and reliability (Kim et al., 2010 and BCA 1997). Furthermore, the benefits of operating PF fibers in foamed concrete have been growing speedily because it enhances the strength behavior, toughness, impact strength and also failure pattern of foamed concrete [16]. In recent decade, experimental work is generally time and energy taking, where great number of materials need to be used and great numbers of samples require to be investigated in order to examine the behavior. Meanwhile, finite element method is the numerical approach which is widely utilized to investigate structural behavior, thermal conductivity, lubrication, electric and magnetic fields (Raju et al., 2014).

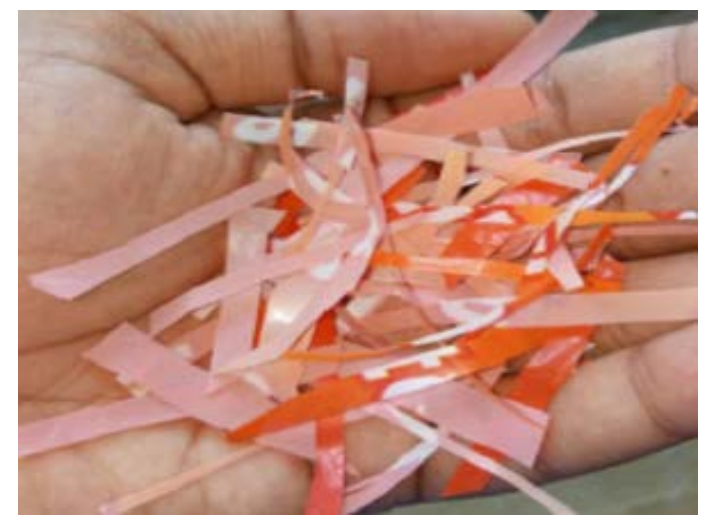

Fig. 1 - The plastic fibers which was utilized in research

In this research the foamed concrete beam were analyzed by experimentally and FEA under flexural load. The beam was tested in four point bending method. The ultimate load, load deflection profile of beams was investigated by FEA validated with FEA.

\section{Methods and analysis}

The three beams different were casted incorporating $0.6 \%$ plastic fibers which was optimum percentage obtained from literature and control beams. Two concrete beam types were casted. The foamed beams, having dimensions 100mmx200mmx1000mm, were tested for under four-point loading testing flexural strength test for beams. The three LDVTs were installed exactly at the middle portion of foamed concrete beam. The simply supported boundary conditions were used. In FEA, the three dimensional, 3-D models were generated by adopting ABAQUS software to analyses the foamed concrete beam behavior underneath flexure loading. The ABAQUS/explicit analysis was utilized for foamed concrete beam analysis. The data was obtained from the experimental and handouts of ABAQUS 2009 specification as presented in Table 1 . The results were investigated in the context of its ultimate load and loaddeflection pattern. The FEA study was escorted by means of emerging sequence of simulations on foamed concrete beam. The purpose of this parametric study was to inspect the impact of various main reinforcement areas and to identify the optimum main reinforcement area in situation of its ultimate bearing capacity strength achieved. All the foamed concrete beams specimen was modelled consisting plastic fibers. Concrete cover was $25 \mathrm{~mm}$, main reinforcement having $12 \mathrm{~mm}$ diameter and stirrups of $6 \mathrm{~mm}$ diameter were exploited for all specimen. Various main reinforcement steel such as $14 \mathrm{~mm}$ to $20 \mathrm{~mm}$ by increasing $2 \mathrm{~mm}$ were used for parametric study. The material properties, dimension, convergence study and concrete damage plasticity of foamed concrete are presented in Table 1 , Table 2, Table 3 and Table 4. 
Table 1 - Dimensions and properties of reinforcement

\begin{tabular}{ccccc}
\hline Samples & Dimensions & $\mathbf{A}_{\mathbf{v}} / \mathbf{d}$ & $\begin{array}{c}\text { Diameter of } \\
\text { main } \\
\text { reinforcement }\end{array}$ & $\begin{array}{c}\text { Diameter of } \\
\text { Stirrups }\end{array}$ \\
\hline Control & $100 \mathrm{X} 200 \mathrm{X} 1000$ & 1.8 & $12 \mathrm{~mm}$ & $\mathrm{R} 6$ \\
$0.6 \% \mathrm{FCB}$ & $100 \mathrm{X} 200 \mathrm{X} 1000$ & 1.8 & $12 \mathrm{~mm}$ & $\mathrm{R} 6$ \\
\hline
\end{tabular}

Table 2 - Properties of foamed concrete

\begin{tabular}{|c|c|c|c|c|}
\hline Specimen & $\mathrm{F}_{\mathrm{c}}$ (Mpa) & $\mu$ & $F_{t}($ Mpa) & $\begin{array}{c}E \\
\left(\mathrm{kN} / \mathrm{mm}^{2}\right)\end{array}$ \\
\hline Control & 14 & 0.12 & 0.8 & 14 \\
\hline
\end{tabular}

Table 3 - Properties of reinforcement

\begin{tabular}{|c|c|c|c|c|c|c|}
\hline Reinforcement & $\sigma_{\mathrm{y}}(\mathrm{MPa})$ & Pt (MPa) & $\begin{array}{c}\text { Mass } \\
\text { density } \\
\left(\mathrm{kg} / \mathrm{m}^{3}\right)\end{array}$ & $\mathbf{v}$ & $\begin{array}{c}\text { Es (kN/ } \\
\text { mm²) }^{2}\end{array}$ & $\boldsymbol{\mu}$ \\
\hline Main & 540 & 614 & $7.8 \times 10^{6}$ & 0 & 193 & 0.19 \\
\hline Stirrups & 490 & 523 & $7.8 \times 10^{6}$ & 0 & 205 & 0.19 \\
\hline
\end{tabular}

Table 4 - Concrete damage plasticity of foamed cconcrete

\begin{tabular}{|c|c|c|c|c|c|}
\hline $\begin{array}{c}\text { Dilatation } \\
\text { Angle } \\
\end{array}$ & Eccentricity & \multicolumn{2}{|c|}{$\begin{array}{c}\text { Initial biaxial/ uniaxial } \\
\text { ratio, } \sigma_{\mathrm{c} 0} / \sigma_{\mathrm{b} 0}\end{array}$} & $\mathbf{K}$ & Viscosity \\
\hline $29^{\circ}$ & 1 & \multicolumn{2}{|c|}{1.14} & 0.7 & 0 \\
\hline \multicolumn{6}{|c|}{ Control Sample } \\
\hline \multicolumn{3}{|c|}{ Compressive Behavior } & \multicolumn{3}{|c|}{ Tensile Behavior } \\
\hline $\begin{array}{l}\text { Yield } \\
\text { Stress, } \\
(\mathrm{MPa})\end{array}$ & $\begin{array}{l}\text { Inelastic } \\
\text { Strain }\end{array}$ & $\begin{array}{l}\text { Damage } \\
\text { Parameter }\end{array}$ & $\begin{array}{l}\text { Yield Stress } \\
\text { (MPa) }\end{array}$ & $\begin{array}{c}\text { Cracking } \\
\text { Strain }\end{array}$ & $\begin{array}{l}\text { Damage } \\
\text { Parameter }\end{array}$ \\
\hline 12 & 0.000629 & 0.000 & 0.3 & 0 & 0 \\
\hline 15 & 0.017165 & 0.512 & 0.8 & 0.04241 & 0.214 \\
\hline 14 & 0.012677 & 0.921 & 0.5 & 0.061245 & 0.712 \\
\hline \multicolumn{6}{|c|}{$\begin{array}{l}\text { 0.6\% Plastic Fiber Foamed Concrete Beam } \\
\end{array}$} \\
\hline \multicolumn{3}{|c|}{ Compressive Behavior } & \multicolumn{3}{|c|}{ Tensile Behavior } \\
\hline $\begin{array}{l}\text { Yield } \\
\text { Stress, } \\
(\mathrm{MPa})\end{array}$ & $\begin{array}{l}\text { Inelastic } \\
\text { Strain }\end{array}$ & $\begin{array}{l}\text { Damage } \\
\text { Parameter }\end{array}$ & $\begin{array}{l}\text { Yield Stress } \\
\text { (MPa) }\end{array}$ & $\begin{array}{l}\text { Cracking } \\
\text { Strain }\end{array}$ & $\begin{array}{l}\text { Damage } \\
\text { Parameter }\end{array}$ \\
\hline 15 & 0.000712 & 0.000 & 0.5 & 0 & 0 \\
\hline 19 & 0.018124 & 0.664 & 1.2 & 0.03215 & 0.471 \\
\hline 16 & 0.015244 & 0.891 & 0.7 & 0.07123 & 0.837 \\
\hline
\end{tabular}




\subsection{Material Modelling}

In this research the concrete solid element was modelled by utilizing 3D solid element C3D8R Abaqus which is shown in Figure 2.

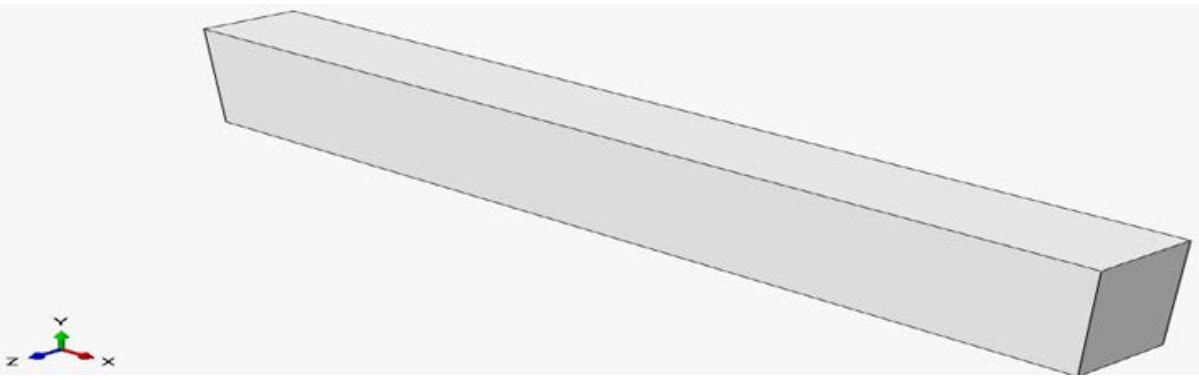

Fig. 2 - load deflection profile of foamed concrete beams

The steel reinforcement which contains the main reinforcement and stirrups was modelled utilizing 3D truss element named as T3D3 by using Abaqus software as present in the Figure 3 and Figure 4.
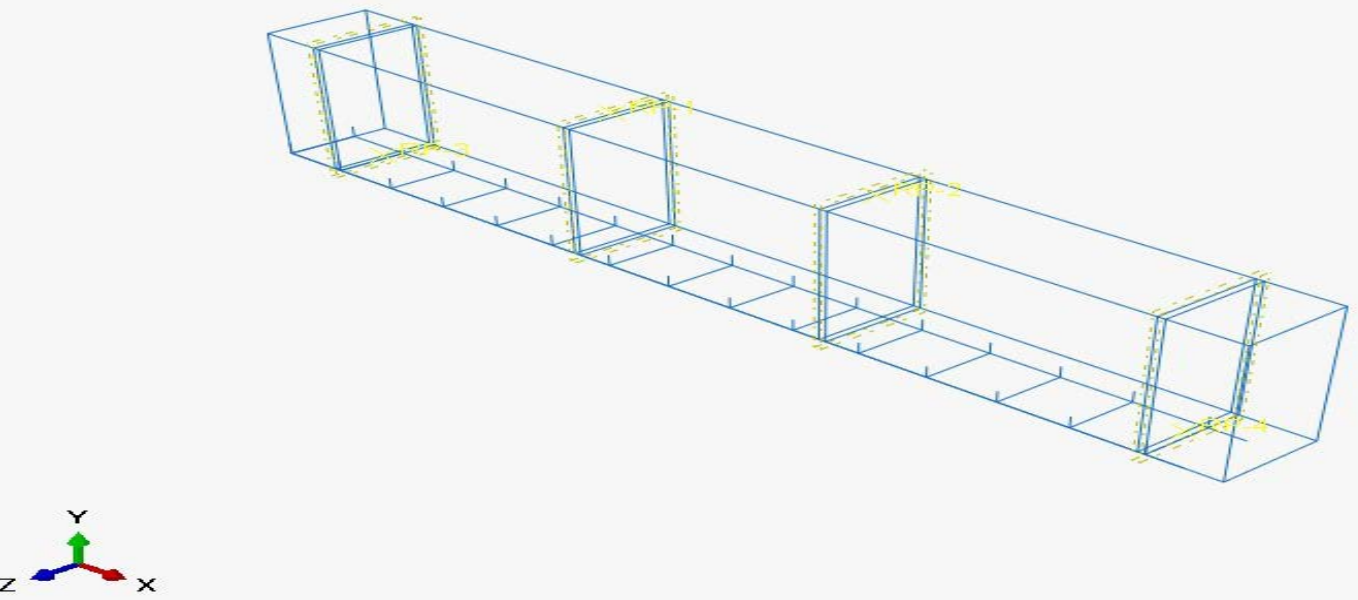

Fig. 3 - The 3D model of main reinforcement and stirrups

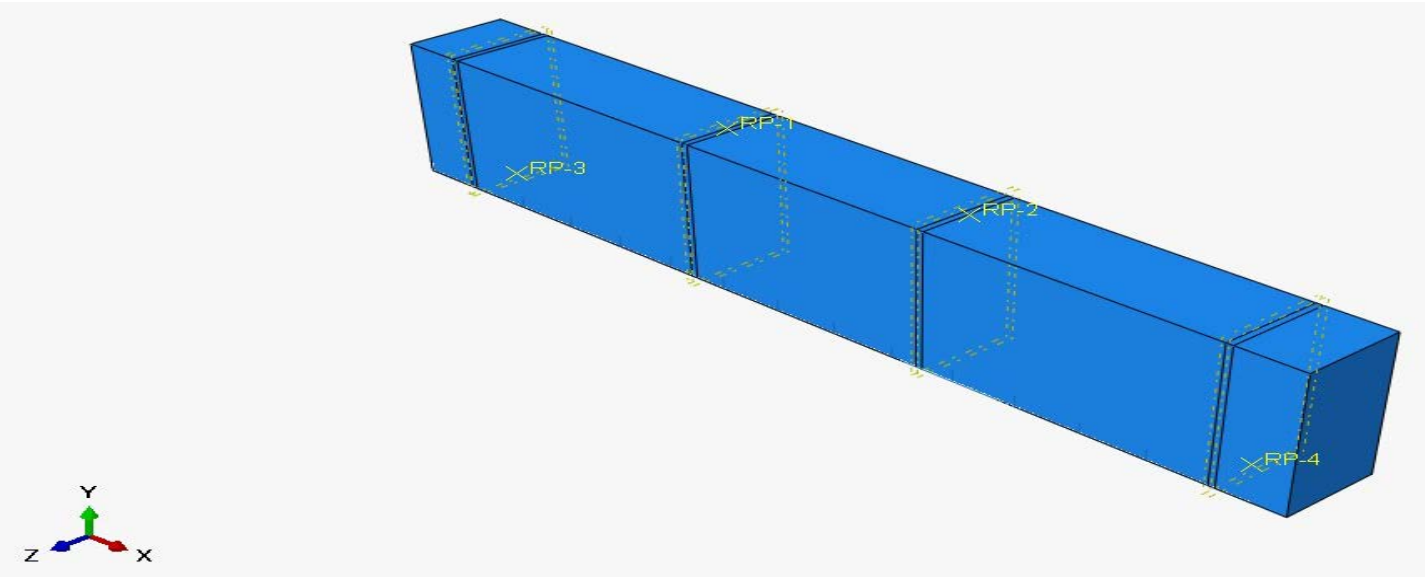

Fig. 4 - The assembly of foamed concrete beam 
The model was discretized into finite element by meshing perception beforehand submission of loading complaint. Figure 5 displays the finite element meshing of foamed concrete beam.

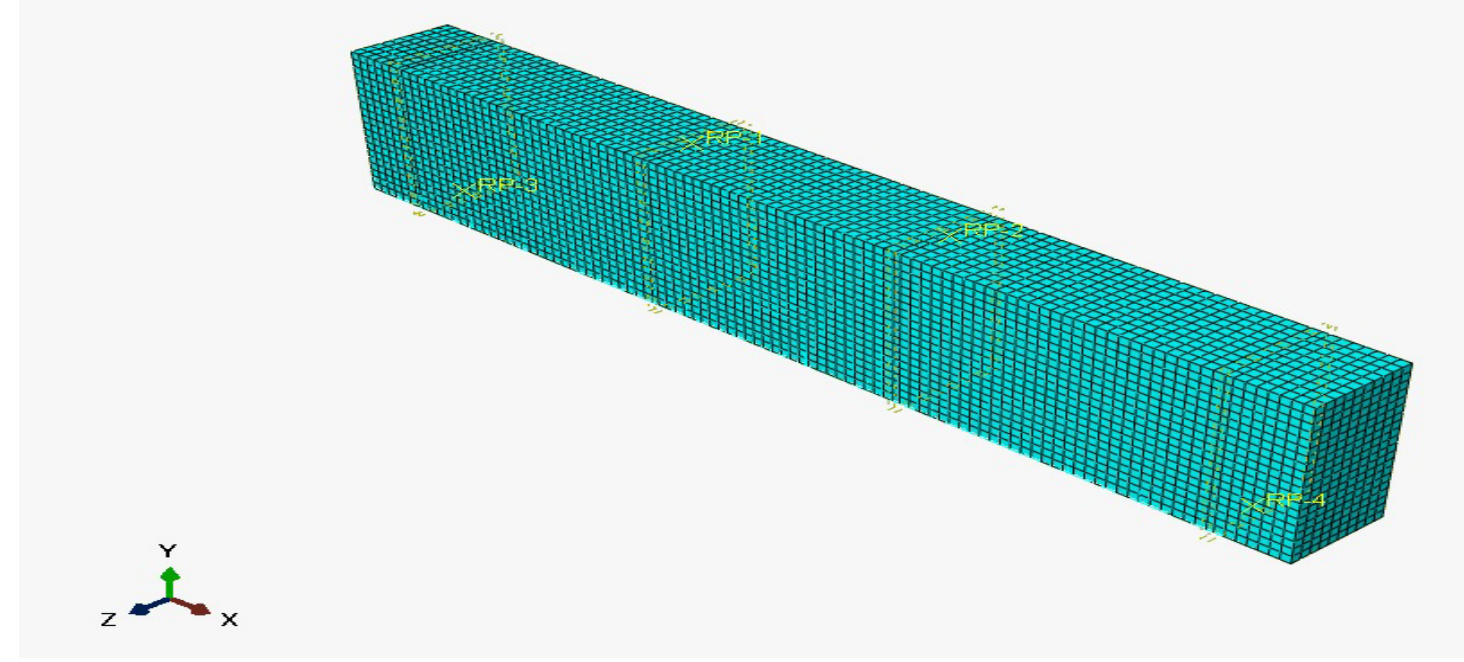

Fig. 5 - Meshing of foamed concrete beam

The two point loading conditions were applied at one third length form supports and the boundary conditions were similar as the experimental like simply support condition where $\mathrm{X}$ and $\mathrm{Y}$ direction was fixed as display in Figure 6. Displacement was owed at $\mathrm{Y}$ direction at the position point or reference on the stiff body to simulate the applied loading on the top of the beam.

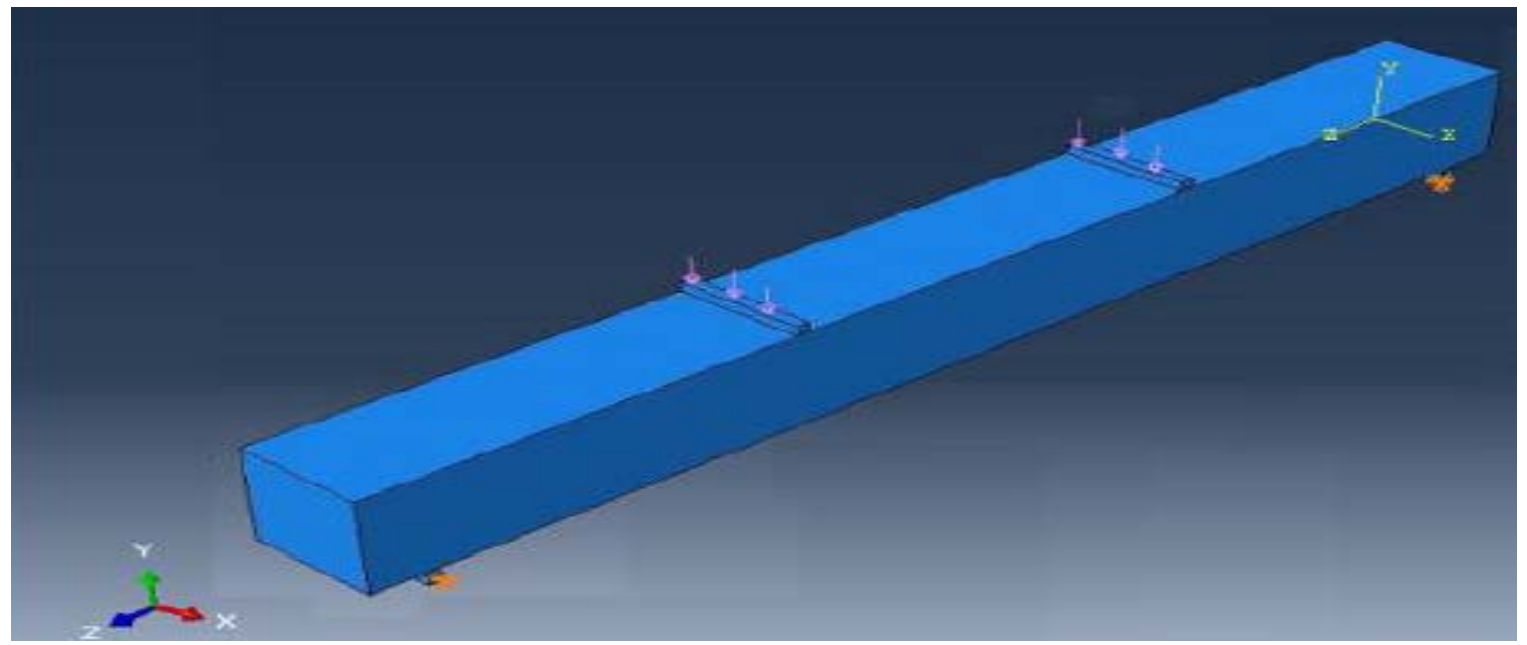

Fig. 6 - The Loading and boundary conditions of foamed concrete beam

\section{Results and Discussions}

The all the beams were tested under four point bending test while the shear span length over depth ratio $\left(a_{v} / d\right)$ was 1.8. The ultimate load of control and $0.6 \% \mathrm{PF}$ foamed concrete beams is shown in Table 5 . From Table 5 it can be seen that the $0.6 \% \mathrm{PF}$ foamed concrete beam possesses the maximum ultimate bearing capacity compared to the control because with the incorporation of PF the internal bonding between the ingredients increases which is responsible for highest bearing capacity. According to Lakhiar et al., (2018c), who analyses the flexural performance of concrete beam consisting the PF. The outcomes demonstrate that the incorporation of PF the flexural strength of concrete increases.

Table 5 - Ultimate load of foamed concrete beams

\begin{tabular}{ccc}
\hline Specimen & No. of Beams & $\begin{array}{c}\text { Ultimate } \\
\text { Load (kN) }\end{array}$ \\
\hline Control & 3 & 23 \\
$0.6 \%$ PF FCB & 3 & 37 \\
\hline
\end{tabular}


The Load deflection profiles of foamed concrete are presented in Figure 7. The results predicted that with the addition of PF the ductility of foamed concrete beams increases. The maximum deflection of control and $0.6 \%$ PF FCB were $6 \mathrm{~mm}$ and $4 \mathrm{~mm}$ respectively at the ultimate load which shows that the incorporation of PF in foamed concrete the deflection of beams improved.

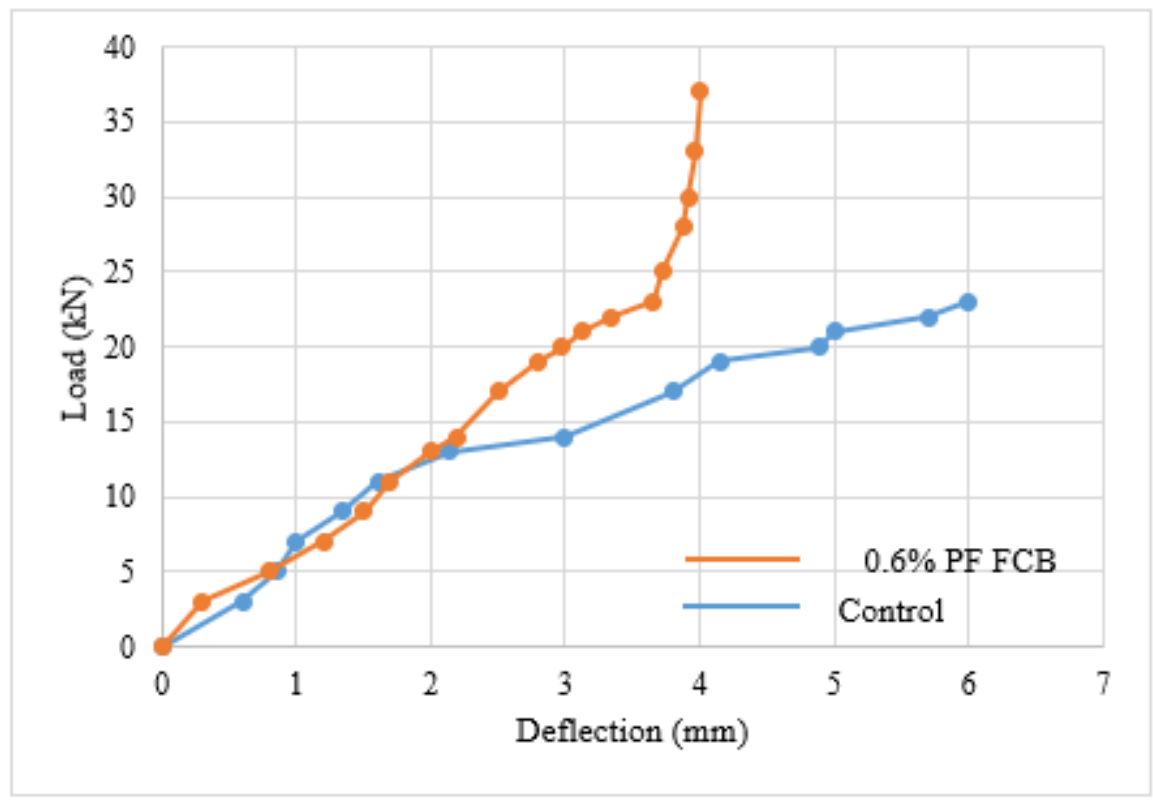

Fig. 7 - Load deflection profile of föamed concrete beams

The cracking patterns of foamed concrete beams are presented in Figure 8 and Figure 9, which presents that the incorporation of PF the crack pattern improves. The control sample possesses the great cracks at flexural portion whereas on the $0.6 \%$ PF foamed concrete beam has less cracks which shows the enhancement in crack propagation.

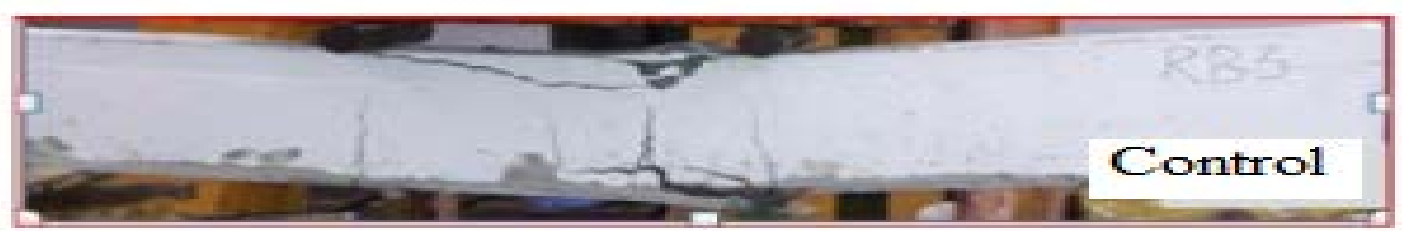

Fig. 8 - Crack pattern of control beams

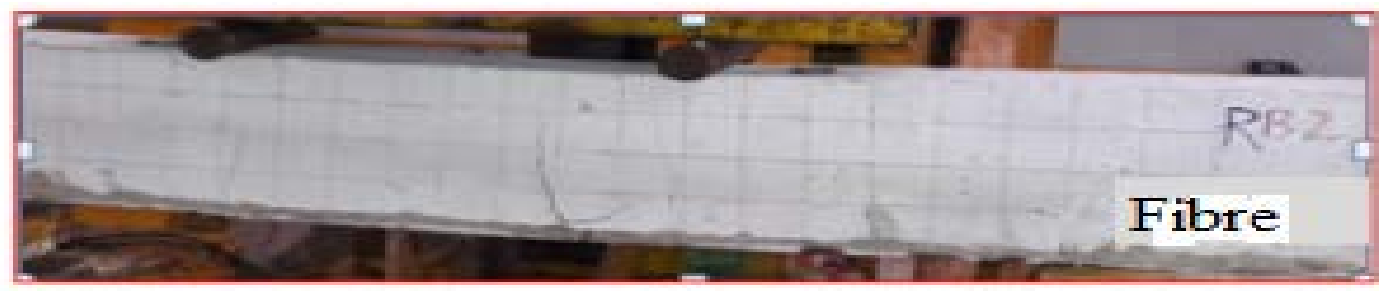

Fig. 9 - Crack pattern of 0.6\% PF FCB 
The FEM model of beams was validated in context of ultimate load and maximum load deflection. Table 6, Table 7 and Table 8 . The ultimate load of control and 0.6\% PF FCB obtained from FEA was 3 to $5 \%$ maximum compare to the experimental analysis. Whereas the maximum deflection of control and 0.6\% PF FCB was 5 to $9 \%$ lower than the experimental analysis.

Table 6 - Ultimate load of foamed concrete beams

\begin{tabular}{|c|c|c|c|}
\hline \multirow[b]{2}{*}{ Specimen } & \multicolumn{2}{|c|}{ Ultimate Load } & \multirow{2}{*}{$\frac{P_{u(F E A)}-P_{u(E X P)}}{P_{u(E X P)}} \times 100 \%$} \\
\hline & Experiment & FEA & \\
\hline Control & 23 & 24 & $4.2 \%$ \\
\hline $0.6 \%$ PF FCB & 37 & 39 & $5.5 \%$ \\
\hline
\end{tabular}

Table 7 - Maximum deflection of foamed concrete beams

\begin{tabular}{|c|c|c|c|}
\hline \multirow[b]{2}{*}{ Specimen } & \multicolumn{2}{|c|}{ Maximum Deflection } & $P_{u(F E A)}-P_{u(E X P)} \times 1000 \%$ \\
\hline & Experiment & FEA & $P_{u(E X P)} \times 100 \%$ \\
\hline Control & 6 & 5.5 & $8.2 \%$ \\
\hline $0.6 \%$ PF FCB & 4 & 3.7 & $7.3 \%$ \\
\hline
\end{tabular}

The parametric study was conducted by utilizing the various reinforcement areas to investigate the ultimate load and max deflection of $0.6 \%$ PF FCB are presented in the Table 8. The results show that increment of main reinforcement are the ultimate load increases whereas the maximum deflection of beam was decreases.

Table 8 - Properties of foamed concrete

\begin{tabular}{cccc}
\hline Specimen & $\begin{array}{c}\text { Main } \\
\text { Reinforcement } \\
\text { Diameters }\end{array}$ & $\begin{array}{c}\text { Ultimate } \\
\text { Load (kN) }\end{array}$ & $\begin{array}{c}\text { Maximum } \\
\text { Deflection } \\
(\mathbf{m m})\end{array}$ \\
\hline $0.6 \%$ PF FCB & $14 \mathrm{~mm}$ & 42 & 3.5 \\
\hline $0.6 \%$ PF FCB & $16 \mathrm{~mm}$ & 48 & 2.9 \\
\hline $0.6 \%$ PF FCB & $18 \mathrm{~mm}$ & 53 & 2.65 \\
\hline $0.6 \%$ PF FCB & $20 \mathrm{~mm}$ & 62 & 2.45 \\
\hline
\end{tabular}

\section{Conclusion}

The experimental investigation results in terms of ultimate load and load deflection profiles demonstrates that the 0.6\% PF FCB had higher ultimate load because of the PF which improves the loading bearing capacity compare to the control beam. The load deflection profile predicts that the incorporation of PF the ductility of beam reduces but the stiffness in $0.6 \%$ PF FCB increased. The FEA and experimental analysis shows the 5 to $8 \%$ difference in outcomes which predicts that FEA could be utilized to investigate the flexural performance of foamed concrete beam to save the energy, time and cost of the structure. The parametric study concludes that the ultimate load increases with the increment of main reinforcement diameter. The deflection was decreases as the diameter of main reinforcement increases.

\section{Acknowledgement}

The authors would like to acknowledge the Department of Civil Engineering Quaid-e-Awam University of Engineering Science \& Technology, Nawabshah, Pakistan for providing testing facilities and funding for conduct of this research. 


\section{References}

Aghaee, K., \& Yazdi, M. A. (2014). Waste steel wires modified structural lightweight concrete. Materials Research, 17(4), 958-966.

Ahmad, O. A., \& Awwad, M. (2015). The effects of polypropylene fibers additions on compressive and tensile strengths of concrete. Int. J. of Civil and Environmental Engineering, 37(1), 1365-1372.

Aldrigde D., Introduction to foamed concrete: What, why, how? Used of foamed concrete in construction, Thomas Telford, Scotland, United Kingdom, (2005).

Bing, C., Zhen, W., \& Ning, L. (2011). Experimental research on properties of high-strength foamed concrete. Journal of materials in civil engineering, 24(1), 113-118.

British Cement Association, “Foamed Concrete Composition and Properties”, British Cement Association 1994.

Goh, W. I., Mohamad, N., Abdullah, R., \& Samad, A. A. A. (2014). Compression test and finite element analysis of foamed concrete cube. Journal of Engineering and Technology (JET), 5(1), 1-10.

Hamad, A. J. (2014). Materials, production, properties and application of aerated lightweight concrete. International journal of materials science and engineering, 2(2), 152-157.

Kim. Y, Jiong. H, Jae. L, and Heeyou. B, (2010). “Mechanical Properties of Fiber Reinforced Lightweight Concrete Containing Surfactant”, Advances in Civil Engineering, 10 , 1-9.

Lakhiar, M. T., Mohamad, N., Jhatial, A. A., Sohu, S., \& Oad, M. (2018a). Mechanical Properties of Concrete Containing River Indus Sand and Recyclable Concrete Aggregate. Civil Engineering Journal, 4(8), 1869-1876.

Lakhiar, M. T., Mohamad, N., Shaikh, M. A. B., Vighio, A. A., Jhatial, A. A., \& Samad, A. A. (2018b). Effect of River Indus Sand on Concrete Tensile Strength. Engineering Technlogy \& Applied Science Research, 8(2), 2796-2798.

Lakhiar, M. T., Sohu, S., Bhatti, I. A., Bhatti, N., Abbasi, S. A., \& Tarique, M. (2018c). Flexural Performance of Concrete Reinforced by Plastic Fibers. Engineering, Technology \& Applied Science Research, 8(3), 3041-3043.

Madhavi, T. C., Raju, L. S., \& Mathur, D. (2014). Polypropylene fiber reinforced concrete-a review. International journal of emerging technology and advanced engineering, 4(4), 114-118.

Mohamad, N., Goh, W. I., Abdullah, R., Samad, A. A. A., Mendis, P., \& Sofi, M. (2017). Structural performance of FCS wall subjected to axial load. Construction and Building Materials, 134, 185-198.

Narayanan, N., \& Ramamurthy, K. (2000). Structure and properties of aerated concrete: a review. Cement and Concrete composites, 22(5), 321-329.

Ramamurthy, K., Nambiar, E. K., \& Ranjani, G. I. S. (2009). A classification of studies on properties of foam concrete. Cement and concrete composites, 31(6), 388-396.

Tang, W. C., Wang, Z., Liu, Y., \& Cui, H. Z. (2018). Influence of red mud on fresh and hardened properties of selfcompacting concrete. Construction and Building Materials, 178, 288-300.

Thakrele, M. H. (2014). Experimental study on foam concrete. International journal of Civil Structure Environment Infrastructure Engineering Research and development (IJCSEIERD), 4(1-2014), 145-158. 